\title{
Transport of Zn (II) by TDDA-Polypropylene Supported Liquid Membranes and Recovery from Waste Discharge Liquor of Galvanizing Plant of Zn (II)
}

\author{
Hanif Ur Rehman, ${ }^{1}$ Gul Akhtar, ${ }^{2}$ Haroon Ur Rashid, ${ }^{1}$ Nauman Ali, ${ }^{2}$ Imtiaz Ahmad, \\ Saeed Ur Rehman, ${ }^{2}$ Kamin Khan, ${ }^{1}$ and Muhammad Arshad ${ }^{3}$ \\ ${ }^{1}$ Department of Chemistry, Sarhad University of Science \& Information Technology, Peshawar, Khyber Pakhtunkhwa, Pakistan \\ ${ }^{2}$ Institute of Chemical Sciences, University of Peshawar, Peshawar, Khyber Pakhtunkhwa, Pakistan \\ ${ }^{3}$ Chemistry Division, Directorate of Science, PINSTECH, Nilore, Islamabad, Pakistan \\ Correspondence should be addressed to Hanif Ur Rehman; chem.ics.edu.pk@gmail.com and Nauman Ali; nali75pk@upesh.edu.pk
}

Received 11 April 2017; Revised 30 July 2017; Accepted 13 August 2017; Published 2 November 2017

Academic Editor: Thijs A. Peters

Copyright ( 2017 Hanif Ur Rehman et al. This is an open access article distributed under the Creative Commons Attribution License, which permits unrestricted use, distribution, and reproduction in any medium, provided the original work is properly cited.

The facilitated passage of $\mathrm{Zn}$ (II) across flat sheet supported liquid membrane saturated with TDDA (tri-n-dodecylamine) in xylene membrane phase has been investigated. The effect of acid and metal ion concentration in the feed solution, the carrier concentration in membrane phase, stripping agent concentration in stripping phase, and coions on the extraction of $\mathrm{Zn}$ (II) was investigated. The stoichiometry of the extracted species, that is, complex, was investigated on slope analysis method and it was found that the complex $(\mathrm{LH})_{2} \cdot \mathrm{Zn}\left(\mathrm{Cl}_{2}\right)$ is responsible for transport of $\mathrm{Zn}$ (II). A mathematical model was developed for transport of $\mathrm{Zn}$ (II), and the predicted results strongly agree with experimental ones. The mechanism of transport was determined by coupled coion transport mechanism with $\mathrm{H}^{+}$and $\mathrm{Cl}^{-}$coupled ions. The optimized SLM was effectively used for elimination of $\mathrm{Zn}$ (II) from waste discharge liquor of galvanizing plant of $\mathrm{Zn}$ (II).

\section{Introduction}

Over the past few decades, the prompt boost in the utilization of heavy metals has increased the flux of metallic ingredients into soils and natural water resources. The presence of even small amount of heavy metals in the environment is hazardous as the majority of them are harmful and persistent [1]. The zinc concentration in the earth crust is about $70 \mathrm{ppm}$. Zinc and its compounds have many applications and are used in galvanization, alloys, catalysts, wood preservation, vulcanization for rubber, photographic paper, ceramics, fertilizers, textiles, batteries, pigments and as dietary supplements and in medicines [2,3].

About two billion people suffer from zinc deficiency in the developing countries and this thus causes various disorders in them. In minors, zinc deficiency is responsible for growth retardation, infection susceptibility, delayed sexual maturation, and diarrhea. These disorders lead to the deaths of about 800,000 children throughout the world every year.

Excess of zinc in the human body has been associated with system dysfunction which in turn can affect growth and reproduction. The presence of free zinc ion in solution has been reported to be very toxic for vertebrates, invertebrates, and plants [4-6]. Due to its toxic effect, large scale applications, and increasing demand for pure zinc, it is necessary to remove and separate zinc from industrial effluents.

Traditional techniques of recovery for metal ions, such as adsorption [7, 8], solvent extraction [9-12], precipitation [13], and ion exchange [14]. have normally low efficiency, require high capital and operating cost, and produce secondary pollution complications [15]. Among novel techniques suggested for transport of metal ions, supported liquid membrane is one of the promising methods. The technique comprises the applications of solvent extraction (high selectivity and 
distribution coefficient) while overcoming usual extraction's shortcomings (loss of carrier due to emulsification and dispersion) [16-18].

Kanungo and Mohapatra [19] investigated the transport of $\mathrm{Zn}$ (II) through supported liquid membrane using bis(2,4,4-trimethylpentyl)phosphinic acid as a metal ion carrier. A model for the rate of transport of binary and ternary complex species has been discussed. The transport of $\mathrm{Zn}$ (II) via di-(2-ethylhexyl)phosphoric acid supported liquid membrane has been studied by Ata et al. [20]. The influence of $\mathrm{pH}$ of feed solution, carrier, and stripping agent concentration, temperature, and flow rate of feed and stripping solution on the transport of $\mathrm{Zn}$ (II) has been investigated. Wódzki and Szczepański found simultaneous recovery and bifurcation of $\mathrm{Zn}$ (II) and $\mathrm{Cu}$ (II) by means of two parallel BLMs. The two selective carriers, 5-nonylsalicylaldoxime and di-(2-ethylhexyl), were employed for transport of $\mathrm{Zn}$ (II) and $\mathrm{Cu}$ (II), respectively [21]. The selective removal of $\mathrm{Zn}$ (II) from other transition metals and transport across polymer inclusion membrane was investigated by Ulewicz and his coworkers [22]. It has been observed that transport selectivity of $\mathrm{Zn}$ (II) over Ni (II), Co (II), Cd (II), and Cu (II) decreases while increasing $\mathrm{pH}$ of the feed solution. Furthermore, it has been studied that $\mathrm{Zn}$ (II) can be selectively eliminated from dilute aqueous feed solution by solvent extraction. Kozlowska et al. studied the competitive transport of $\mathrm{Zn}$ (II), Cd (II), and $\mathrm{Pb}$ (II) through polymer inclusion membranes having organophosphorous acids as an ion carrier [23]. The nature of the extractants on cation efficiency and selectivity has been elaborated. Torz et al. reported the transport of $\mathrm{Zn}$ (II) from hydrochloric acid feed solution through hollow fiber modules using tributyl phosphate as a carrier [24]. It has been observed that the kinetics of the mass transfer process was restricted by the diffusion of species in the membrane openings. Lee et al. investigated the separation of zinc and copper by hollow fiber supported liquid membrane containing LIX 84 and PC-88A as mobile carriers. The influence of numerous operational factors on separation and permeation rate of $\mathrm{Zn}$ (II) and $\mathrm{Cu}$ (II) has been studied [25].

In our previous papers [26-29], an effort was made to design a model for transport of $\mathrm{Ag}$ (I), Mn (II), Pb (II), and Tl (III), through SLM using various carriers and diluents, and successfully applied to industrial waste effluents.

The present work elaborates the extraction and separation of $\mathrm{Zn}$ (II) from aqueous acidic feed solution through flat sheet supported liquid membrane using TDDA as a mobile carrier. In SLM studies, the influence of several process parameters like acid concentration in the feed solution, $\mathrm{Zn}$ (II) concentration in the feed solution, the carrier concentration in membrane phase, and $\mathrm{NaOH}$ concentration in strip solution on the $\mathrm{Zn}$ (II) flux was investigated. Another aim of current work was to investigate the species formed during the transport of $\mathrm{Zn}$ (II) and mechanism of $\mathrm{Zn}$ (II) and further to establish the stoichiometry of the chemical reactions through SLM. Furthermore, this study was concentrated to ascertain the most optimum conditions for transport of $\mathrm{Zn}$ (II), especially for its large scale separation and recovery from industrially galvanizing waste effluents of $\mathrm{Zn}$ (II). No such investigations have been done so far using TDDA SLM system for transport of $\mathrm{Zn}$ (II).

\section{Theory}

Transport of metal ion through SLM occurs by diffusion of metal-carrier complex via various basic steps. First, the metal ion diffuses across aqueous diffusion layer from aqueous bulk feed solution to membrane feed interface and the metalcarrier complex is prepared at feed membrane interface. The complex is then diffused through liquid membrane phase to strip membrane interface owing to the concentration gradient. The complex is finally dissociated at strip membrane interface, carrier returns back across liquid membrane phase, and metal ion diffuses through aqueous diffusion layer into bulk strip solution. The theoretical model of mass transfer of $\mathrm{Zn}$ (II) for this purpose is important for the diffusion of metal-carrier complex.

\section{Experimental}

3.1. Chemicals and Reagents. $\mathrm{ZnCl}_{2}(97 \% \mathrm{BDH})$ in $\mathrm{HCl}(37 \%$ Merck) was used as feed in various concentration. $\mathrm{NaOH}$ (99-100\% Merck) in distilled water in various concentrations was used as a stripping solution and TDDA ( $\geq 95 \%$ Merck) with diluent xylene (99.5\%) to get the various composition of metal ion carrier. Double distilled and deionized water was used in all experiments. All other chemicals used were of analytical or better grade.

3.2. Analytical Instruments. Atomic absorption spectrometer of Perkin Elmer model 400 was used to measure the concentration of zinc (II) and other metal ions in feed and strip solutions. $\mathrm{pH}$ was determined through $\mathrm{pH}$ meter of Metrohm model 827. Viscosity determination of TDDA (in xylene) was performed via viscometer/rheometer of Brookfield LVDVIII.

3.3. Permeation Cell. The metal ion transport study was performed in two-compartment cell made of Perspex material as reported in our previous work [26]. Each half cell of the permeation cell had the volume capacity of $300 \mathrm{~cm}^{3}$ and active membrane area was $23.79 \mathrm{~cm}^{2}$. Each half was equipped with synchronous motors, $\mathrm{pH}$ electrode, and sampling port. The stirring speed of $1500 \mathrm{rpm}$ [26] was optimized for the similar type of permeation cell and carrier; therefore this stirring speed was used in all the permeation study. All the experiments were conducted at $25 \pm 0.5^{\circ} \mathrm{C}$.

3.4. SLM Preparation. The microporous polypropylene thin coating of Celgard 2400 was applied as a solid support for a liquid organic carrier with an active pore size of $0.02 \mu \mathrm{m}$, the thickness of $25 \mu \mathrm{m}$, and porosity of $38 \%$. The membrane was cut into rectangular pieces of $8 \times 6 \mathrm{~cm}$ and was soaked in the premeasured concentration of TDDA diluted with xylene in Petri dish for overnight. The membrane was then taken out from the organic solution. The excess amount of organic carrier and solvent were removed by allowing them to drain off the membrane for about five minutes. 
3.5. SLM Transport Study. The membrane after preparation was placed in between the two compartments of the cell and screwed together to form a water tight seal. Both compartments of the cell were filled with $300 \mathrm{~mL}$ of predetermined concentration of feed and strip solutions. To avoid concentration polarization at feed and strip membrane interfaces, the two solutions in feed and strip compartments were continuously stirred. Samples were collected after a specific time interval from both feed and strip solution and tested for metal ion concentration. For most of the experiments, the carrier concentration was $0.80 \mathrm{~mol} / \mathrm{dm}^{3}$ in xylene.

The flux $(J)$ was calculated as follows [26]:

$$
\text { Flux }=\frac{\text { concentration of } \mathrm{Zn}^{2+} \mathrm{mol} / \mathrm{dm}^{3} \times \text { solution volume in feed or strip }\left(\mathrm{dm}^{3}\right)}{\text { effective membrane area }\left(\mathrm{m}^{2}\right) \times \Delta t} \text {. }
$$

\section{Results and Discussion}

4.1. Reactions at Feed Membrane Interface. If tri-ndodecylamine (TDDA) is represented by $\mathrm{L}$, the following possibilities of reactions may take place. The tri-ndodecylamine can be protonated to $\mathrm{LH}^{+}$in acidic medium $(\mathrm{HCl})$.

$$
\mathrm{L}+\mathrm{H}^{+} \rightleftharpoons \mathrm{LH}^{+}
$$

It is supposed that $\mathrm{ZnCl}_{2}$ in feed solution in the presence of excess chloride ions due to $\mathrm{HCl}$ is converted to

$$
\mathrm{ZnCl}_{2(\mathrm{aq})}+n \mathrm{Cl}^{-}{ }_{(\mathrm{aq})} \longrightarrow\left[\mathrm{Zn}\left(\mathrm{Cl}_{2}+n\right)\right]_{(\mathrm{aq})}^{n-}
$$

The cationic $\left(\mathrm{LH}^{+}\right)($org $)$and anionic species $\left[\mathrm{Zn}\left(\mathrm{Cl}_{2}+n\right)\right]^{n-}$ (aq) then interact at feed membrane interface and form the complex as

$$
\begin{gathered}
n \mathrm{LH}^{+}{ }_{(\mathrm{org})}+\left[\mathrm{Zn}\left(\mathrm{Cl}_{2}+n\right)\right]_{(\mathrm{aq})}^{n-} \\
\rightleftharpoons(\mathrm{LH})_{n} \cdot \mathrm{Zn}\left(\mathrm{Cl}_{2}+n\right)_{(\mathrm{org})}
\end{gathered}
$$

The subscript org represents organic phase and aq aqueous phase and $n$ indicates the number of $\mathrm{Cl}^{-}, \mathrm{H}^{+}$, and $\mathrm{L}$ molecules associating with $\mathrm{Zn}$ (II) ions to form the neutral complex $(\mathrm{LH})_{n} \cdot \mathrm{Zn}\left(\mathrm{Cl}_{2}+n\right)_{(\mathrm{org})}$.

To express the contribution of $\mathrm{H}^{+}$and $\mathrm{Cl}^{-}$, (3) may be represented as

$$
\begin{aligned}
& n \mathrm{~L}_{(\text {org })}+n \mathrm{H}^{+}{ }_{(\mathrm{aq})}+\mathrm{ZnCl}_{2(\mathrm{aq})}+n \mathrm{Cl}^{-}(\mathrm{aq}) \\
& \rightleftharpoons(\mathrm{LH})_{n} \cdot \mathrm{Zn}\left(\mathrm{Cl}_{2}+n\right)_{(\mathrm{org})}
\end{aligned}
$$

4.2. Reactions at Strip Membrane Interface. The neutral complex formed at feed membrane interface as per (3)/(4) is extractable in liquid organic phase and disperses from feed membrane interface to strip membrane interface. The complex at strip membrane interface is dissociated owing to $\mathrm{NaOH}$ in the stripping phase as follows:

$$
\begin{aligned}
& (\mathrm{LH})_{n} \cdot \mathrm{Zn}\left(\mathrm{Cl}_{2}+n\right)_{(\mathrm{org})}+n \mathrm{NaOH} \\
& \longrightarrow \mathrm{Zn}(\mathrm{II})+2 \mathrm{Cl}^{-}+\mathrm{H}_{2} \mathrm{O}+n \mathrm{NaCl}+n \mathrm{~L}
\end{aligned}
$$

The free carrier molecule (L) diffuses back through the liquid membrane phase towards feed membrane interface and again forms the complex. As per Wilke-Chang, the diffusion coefficient of the forward moving complex $(\mathrm{LH})_{n}$. $\mathrm{Zn}\left(\mathrm{Cl}_{2}+n\right)_{\text {org }}$ should be noticeably lesser than the diffusion coefficient of the backward moving free carrier molecules [30]. Owing to this reason, the free carrier concentration at feed membrane interface will constantly be higher than the complex. Figure 1 represents the schematic transport mechanism of $\mathrm{Zn}$ (II) through supported liquid membrane.

The equilibrium constant $K_{\mathrm{Zn}}$ of (4) for $\mathrm{Zn}$ (II) can be written as follows:

$$
K_{\mathrm{zn}}=\frac{\left[(\mathrm{LH})_{n} \cdot \mathrm{Zn}\left(\mathrm{Cl}_{2}+n\right)\right]_{\mathrm{org}}}{[\mathrm{L}]_{\mathrm{org}}^{n} \cdot\left[\mathrm{H}^{+}\right]_{\mathrm{aq}}^{n} \cdot\left[\mathrm{Zn}^{2+}\right]_{\mathrm{aq}} \cdot\left[\mathrm{Cl}^{-}\right]_{\mathrm{aq}}^{n}} .
$$

The distribution coefficient of $\mathrm{Zn}^{2+}\left(\lambda_{\mathrm{zn}}\right)$ for distribution between the membrane and aqueous phases can be represented as follows:

$$
\begin{aligned}
\lambda_{\mathrm{zn}} & =\frac{\left[(\mathrm{LH})_{n} \cdot \mathrm{Zn}\left(\mathrm{Cl}_{2}+n\right)_{n}\right]_{\mathrm{org}}}{\left[\mathrm{Zn}^{2+}\right]_{\mathrm{aq}}}, \\
K_{\mathrm{zn}} & =\frac{\lambda_{\mathrm{zn}}}{[\mathrm{L}]^{n}{ }_{\mathrm{org}} \cdot\left[\mathrm{H}^{+}\right]^{n}{ }_{\mathrm{aq}} \cdot\left[\mathrm{Cl}^{-}\right]^{n}{ }_{\mathrm{aq}}} .
\end{aligned}
$$

And on rearranging of (8),

$$
\lambda_{\mathrm{zn}}=K_{\mathrm{zn}} \cdot[\mathrm{L}]_{\text {org }}^{n} \cdot\left[\mathrm{H}^{+}\right]_{\mathrm{aq}}^{n} \cdot\left[\mathrm{Cl}^{-}\right]_{\mathrm{aq}}^{n}
$$

Now considering the extraction constant, distribution coefficient, and laws of diffusion via the same path as [29], it can be indicated as:

$$
\begin{aligned}
\log J \eta & =\frac{\log y+\log T+n \log [\mathrm{L}]_{\mathrm{org}}+n \log \left[\mathrm{H}^{+}\right]_{\mathrm{aq}}+n \log \left[\mathrm{Cl}^{-}\right]_{\mathrm{aq}}+\log C_{f}}{\ell}, \\
\log J \eta & =\text { constant }+n \log [\mathrm{L}]_{\mathrm{org}}+n \log \left[\mathrm{H}^{+}\right]_{\mathrm{aq}}+n \log \left[\mathrm{Cl}^{-}\right]_{\mathrm{aq}}+\log C_{f}
\end{aligned}
$$




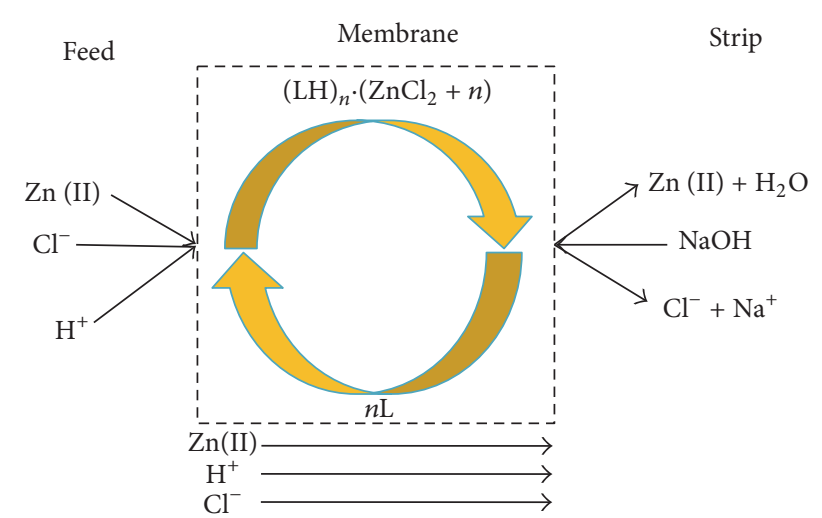

FIGURE 1: Transport mechanism of $\mathrm{Zn}$ (II) through supported liquid membrane.

Equation (11) shows that, at a constant temperature, the flux $(J)$ of $\mathrm{Zn}$ (II) is directly proportional to the concentration of $\mathrm{Cl}^{-}, \mathrm{H}^{+}, \mathrm{L}$, and $\mathrm{C}_{f}$. This equation can be used to find the number of $\mathrm{H}^{+}$related to $\mathrm{L}$ in the form of $\mathrm{LH}^{+}$. This can be determined by various methods: one method is to keep $\left[\mathrm{Cl}^{-}\right],[\mathrm{L}]$, and $C_{f}$ constant in (11) and plotting $\log J \eta$ against $\log \left[\mathrm{H}^{+}\right]$; the slope of the curve will provide the " $n$ " value for a number of $\mathrm{H}^{+}$ions in the complex. Likewise by drawing $\log J \eta$ versus $\log [\mathrm{L}]$ and maintaining $\left[\mathrm{Cl}^{-}\right],\left[\mathrm{H}^{+}\right]$, and $C_{f}$ constant, the slope of the plot will give a number of moles (n) of TDDA contributing in complex formation of $\mathrm{Zn}$ (II).

4.3. Effect of Carrier Concentration. The carrier in the liquid membrane phase of the supported liquid membrane has a critical role in the extraction of metal ions by SLM [26]. Various concentrations of carrier ranging from $0.157 \mathrm{~mol} / \mathrm{dm}^{3}$ to $1.103 \mathrm{~mol} / \mathrm{dm}^{3}$ were used in solvent xylene to observe the effect of carrier concentration on the transport of $\mathrm{Zn}$ (II) through SLM. During this study, the $\mathrm{Zn}$ (II) concentration in feed solution was kept at $7.385 \times 10^{-4} \mathrm{~mol} / \mathrm{dm}^{3}$ in $2.0 \mathrm{~mol} / \mathrm{dm}^{3}$ of $\mathrm{HCl}$ and the $\mathrm{NaOH}$ concentration in strip solution was fixed at $2.0 \mathrm{~mol} / \mathrm{dm}^{3}$.

Figure 2 shows that with the increase of carrier concentration from 0.157 to $0.80 \mathrm{~mol} / \mathrm{dm}^{3}$ in xylene in the membrane phase has a significant effect on flux of $\mathrm{Zn}$ (II). It follows (11) where flux $(J)$ is directly proportional to carrier concentration [L]. However, the flux is insignificant as the concentration of carrier increases beyond $0.80 \mathrm{~mol} / \mathrm{dm}^{3}$. This reduction in transport of $\mathrm{Zn}$ (II) might be the result of enhanced friction of liquid membrane phase owing to high viscosity, as with the increase in carrier concentration, the viscosity of liquid membrane phase increases [29]. Hence $0.80 \mathrm{~mol} / \mathrm{dm}^{3}$ of tri-n-dodecylamine was considered the optimum carrier concentration and more investigations were performed with this concentration of carrier.

Finding the number $(n)$ of tri-n-dodecylamine $(\mathrm{L})$ taking part in complex $(\mathrm{LH})_{n} \cdot \mathrm{Zn}\left(\mathrm{Cl}_{2}+n\right)$ was determined by plotting $\log [$ TDDA] versus $\log J \eta$ as shown in Figure 3. The slope of the plot is 2.008, and this indicates that two molecules of TDDA take part in the complex formation.

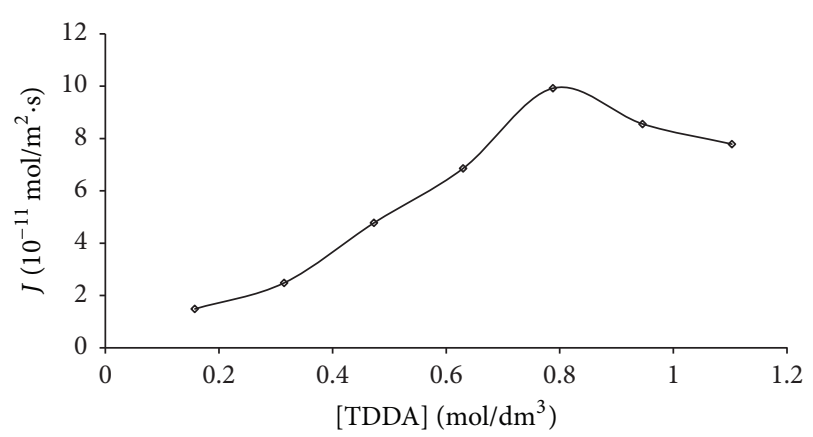

FIGURE 2: Effect of carrier concentration on transport of $\mathrm{Zn}$ (II) in the stripping phase. $[\mathrm{HCl}]$ in feed solution $=2.0 \mathrm{~mol} / \mathrm{dm}^{3}$, [TDDA] in membrane phase $=0.157 \mathrm{~mol} / \mathrm{dm}^{3}$ to $1.103 \mathrm{~mol} / \mathrm{dm}^{3},[\mathrm{NaOH}]$ in stripping solution $=2.0 \mathrm{~mol} / \mathrm{dm}^{3},[\mathrm{Zn}(\mathrm{II})]=7.385 \times 10^{-4} \mathrm{~mol} / \mathrm{dm}^{3}$, time $=5.0 \mathrm{~h}$.

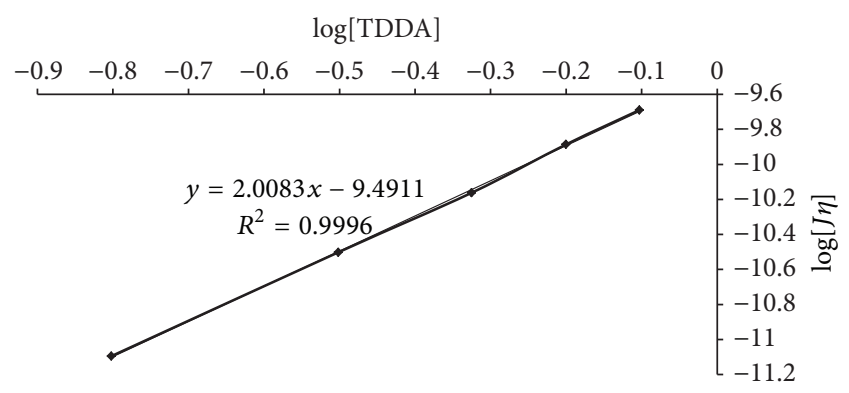

FIgure 3: Plot of $\log [$ TDDA] versus $\log J \eta$ (same operating conditions as given in Figure 2).

In our previous study for the stability of membrane for such type of carrier, it has been observed that supported liquid membrane is quite stable for a period of $120 \mathrm{~h}$ with very minute flux variation in the metal ion flux and no indication of structural deformation of polypropylene membrane was investigated. Furthermore, the membrane was reused several times without leakage and metal ion flux decline [28].

4.4. Role of $\mathrm{HCl}$ Concentration in Feed Phase. The $\mathrm{HCl}$ performs an important part in the transportation of $\mathrm{Zn}$ (II) because it provides $\mathrm{H}^{+}$and $\mathrm{Cl}^{-}$for the formation of complex $(\mathrm{LH}) \mathrm{Zn}\left(\mathrm{Cl}_{2}+n\right)$ as per (4). The effect of $\mathrm{HCl}$ concentration on extraction $\mathrm{Zn}$ (II) was observed by varying the concentration of $\mathrm{HCl}$ in the range of $0.5 \mathrm{~mol} / \mathrm{dm}^{3}$ to $3.0 \mathrm{~mol} / \mathrm{dm}^{3}$, while keeping the concentration of TDDA in the liquid membrane phase at $0.80 \mathrm{~mol} / \mathrm{dm}^{3}$ and concentration of $\mathrm{NaOH}$ on strip side at $2.0 \mathrm{~mol} / \mathrm{dm}^{3}$. Figure 4 shows that as the concentration of $\mathrm{HCl}$ increases from $0.5 \mathrm{~mol} / \mathrm{dm}^{3}$ to $2.0 \mathrm{~mol} / \mathrm{dm}^{3}$ and the flux of $\mathrm{Zn}$ (II) increases. Thus, it can be concluded that with an increase of $\mathrm{HCl}$ concentration, the concentration of $\mathrm{H}^{+}$and $\mathrm{Cl}^{-}$ions in feed solution also increases. This, in turn, increases the formation of the complex as per (4), which ultimately enhances the transport of $\mathrm{Zn}$ (II). Although, by further increasing the concentration of $\mathrm{HCl}$ beyond $2.0 \mathrm{~mol} / \mathrm{dm}^{3}$, the transport of $\mathrm{Zn}$ (II) decreases and this may be due to the formation of $\mathrm{H}_{n} \cdot \mathrm{Zn}\left(\mathrm{Cl}_{2}\right)_{n}$ type species due to the large quantity of $\mathrm{H}^{+}$and $\mathrm{Cl}^{-}$in feed phase and reaction 


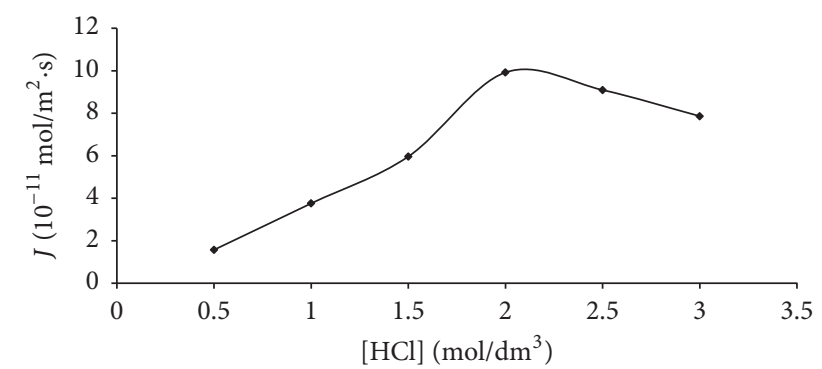

FIGURE 4: Effect of $\mathrm{HCl}$ concentration in feed solution on flux $(J)$ of $\mathrm{Zn}$ (II). [HCl] in feed solution $=0.50 \mathrm{~mol} / \mathrm{dm}^{3}$ to $3.0 \mathrm{~mol} / \mathrm{dm}^{3}$, [TDDA $]$ in membrane phase $=0.80 \mathrm{~mol} / \mathrm{dm}^{3},[\mathrm{NaOH}]$ in stripping solution $=2.0 \mathrm{~mol} / \mathrm{dm}^{3}$, time $=5.0 \mathrm{~h}$.

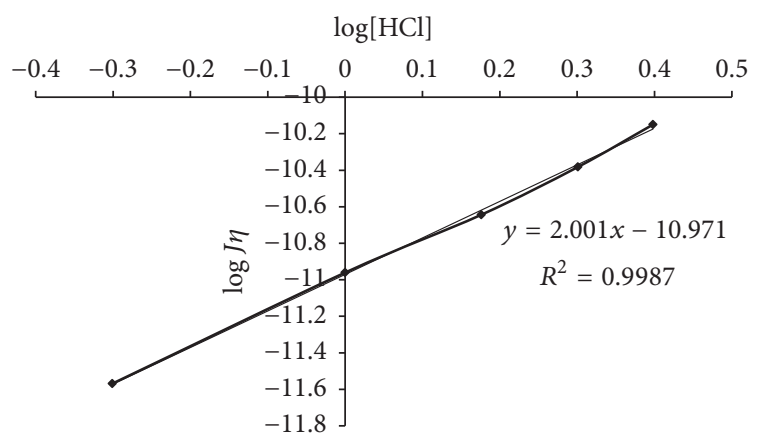

FIGURE 5: Plot of $\log [\mathrm{HCl}]$ versus $\log J \eta$ (same operating conditions as given in Figure 4).

(4) is hindered in forward direction. This study shows that $2.0 \mathrm{~mol} / \mathrm{dm}^{3}$ of $\mathrm{HCl}$ is the most favorable concentration for transport of $\mathrm{Zn}$ (II), and further studies were carried out with this concentration of $\mathrm{HCl}$ to evaluate various parameters for subsequent studies.

To investigate that how much hydrogen is taking part in complexation of $\mathrm{Zn}$ (II), $\log J \eta$ was plotted versus $\log [\mathrm{HCl}]$ (Figure 5). The slope of this plot was approximately 2.0, indicating that two hydrogens take part in a complex of $\mathrm{Zn}$ (II) transport. As the transport study concluded that two molecules of TDDA and $\mathrm{H}^{+}$are involved in the complex formation of $\mathrm{Zn}$ (II), the complex formed during this extraction study may be $(\mathrm{LH})_{n} \cdot \mathrm{Zn}\left(\mathrm{Cl}_{2}+n\right)$.

4.5. Influence of Feed Concentration. To study the capability of this SLM for metal ion transport, various concentrations of $\mathrm{Zn}$ (II) from $3.692 \times 10^{-4} \mathrm{~mol} / \mathrm{dm}^{3}$ to $18.463 \times 10^{-4} \mathrm{~mol} / \mathrm{dm}^{3}$ were used in the feed solution. During this particular study, the concentrations of the carrier, stripping phase, and $\mathrm{HCl}$ in feed solution were kept at $0.80 \mathrm{~mol} / \mathrm{dm}^{3}, 2.0 \mathrm{~mol} / \mathrm{dm}^{3}$, and $2.0 \mathrm{~mol} / \mathrm{dm}^{3}$, respectively.

Figure 6 shows that as $\mathrm{Zn}$ (II) concentration in feed solution rises, the transport of $\mathrm{Zn}$ (II) also increases; this is as per (11), where flux $(J)$ is directly proportional to feed concentration $\left(C_{f}\right)$. Such type behavior has already been studied in our previous study $[27,28]$. This study shows that up to $18.463 \times 10^{-4} \mathrm{~mol} / \mathrm{dm}^{3}$ no saturation of carrier with metal ion takes place.

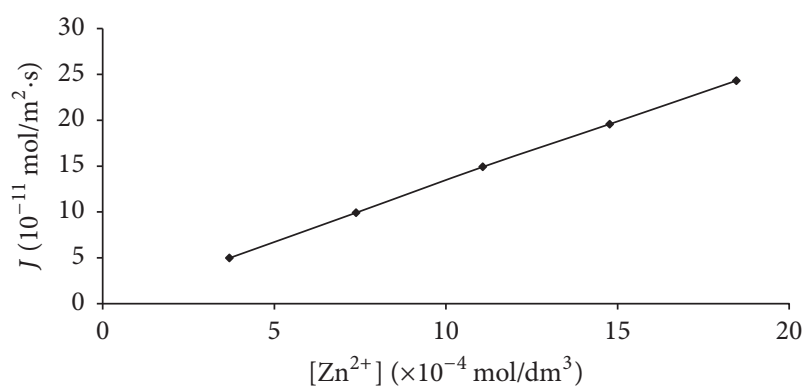

FIGURE 6: Effect of $\mathrm{Zn}$ (II) concentration in feed solution on its flux. $[\mathrm{Zn}(\mathrm{II})]$ in feed $=3.692 \times 10^{-4} \mathrm{~mol} / \mathrm{dm}^{3}$ to $18.463 \times 10^{-4} \mathrm{~mol} / \mathrm{dm}^{3}$, $[\mathrm{HCl}]$ in feed $=2.0 \mathrm{~mol} / \mathrm{dm}^{3},[\mathrm{NaOH}]$ in stripping solution $=$ $2.0 \mathrm{~mol} / \mathrm{dm}^{3},[$ TDDA $]$ in membrane phase $=0.80 \mathrm{~mol} / \mathrm{dm}^{3}$, time $=$ $5.0 \mathrm{~h}$.

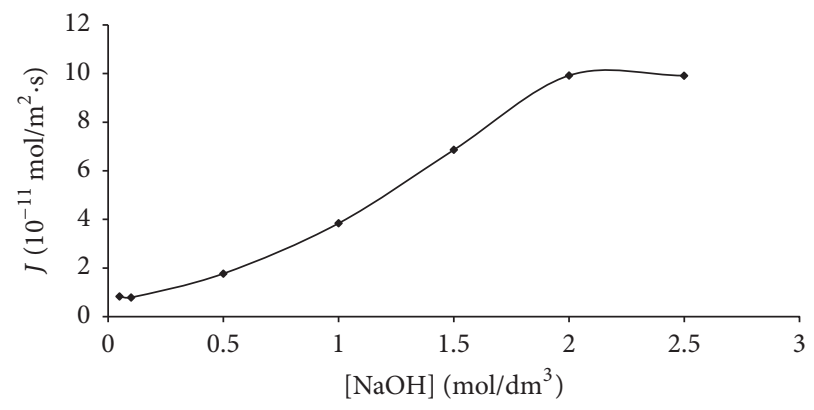

Figure 7: Effect of $\mathrm{NaOH}$ concentration in strip solution on the flux of $\mathrm{Zn}$ (II). [NaOH] in stripping solution $0.05 \mathrm{~mol} / \mathrm{dm}^{3}$ to $2.5 \mathrm{~mol} / \mathrm{dm}^{3},[\mathrm{HCl}]$ in feed solution $=2.0 \mathrm{~mol} / \mathrm{dm}^{3}$, [TDDA] in membrane phase $=0.80 \mathrm{~mol} / \mathrm{dm}^{3}$, time $=5.0 \mathrm{~h}$.

4.6. Influence of Stripping Phase Concentration. The stripping agent dissociates the complex $(\mathrm{LH})_{n} \cdot \mathrm{Zn}\left(\mathrm{Cl}_{2}+n\right)$ at strip membrane interface and releases $\mathrm{Zn}$ (II) in strip solution. To investigate the effect of $\mathrm{NaOH}$ on the transport of $\mathrm{Zn}$ (II), numerous concentrations of $\mathrm{NaOH}$ in the range of $0.05 \mathrm{~mol} / \mathrm{dm}^{3}$ to $2.5 \mathrm{~mol} / \mathrm{dm}^{3}$ were used, while keeping the TDDA concentration at $0.80 \mathrm{~mol} / \mathrm{dm}^{3}$ and $\mathrm{HCl}$ concentration in feed solution at $2.0 \mathrm{~mol} / \mathrm{dm}^{3}$.

Figure 7 shows that as the concentration of $\mathrm{NaOH}$ rises from $0.05 \mathrm{~mol} / \mathrm{dm}^{3}$ to $0.1 \mathrm{~mol} / \mathrm{dm}^{3}$, the flux of $\mathrm{Zn}$ (II) decreases and, beyond this concentration of $\mathrm{NaOH}$, the flux of $\mathrm{Zn}$ (II) increases. The decrease in transport of $\mathrm{Zn}$ (II) at a lower concentration of $\mathrm{NaOH}$ can be explained that it forms a precipitate of $\mathrm{Zn}(\mathrm{OH})_{2}$ which is insoluble and blocks the pores of polypropylene membrane and transport of $\mathrm{Zn}$ (II) is restricted [31]. The SEM (Figure 8(b)) indicates the blocked SLM at a lower concentration of $\mathrm{NaOH}$. More increase in the concentration of $\mathrm{NaOH}$ increases the transportation of $\mathrm{Zn}$ (II), as the precipitate of $\mathrm{Zn}(\mathrm{OH})_{2}$ is soluble in excess of $\mathrm{NaOH}$ and more $\mathrm{OH}^{-}$are available that enhance the decomposition of the complex at strip membrane interface as per (5). 


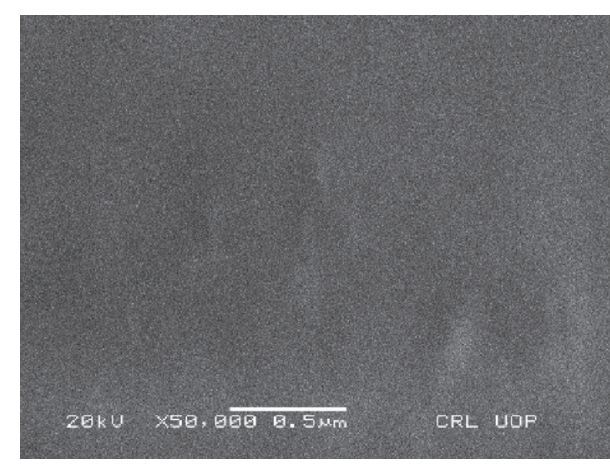

(a) SEM of the membrane before $\mathrm{Zn}$ (II) transport

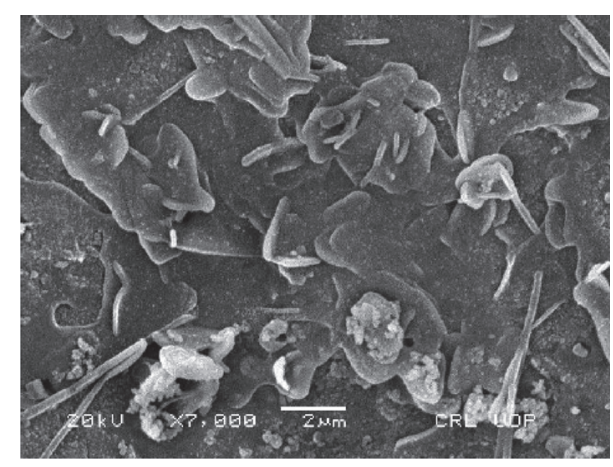

(b) SEM of membrane at $0.1 \mathrm{~mol} / \mathrm{dm}^{3}$ of $\mathrm{NaOH}$ ([HCl] in feed solution $=2.0 \mathrm{~mol} / \mathrm{dm}^{3}$, [TDDA $]$ in membrane phase $=0.80 \mathrm{~mol} / \mathrm{dm}^{3},[\mathrm{Zn}(\mathrm{II})]=7.385 \times$ $\left.10^{-4} \mathrm{~mol} / \mathrm{dm}^{3}\right)$.

FIGURE 8

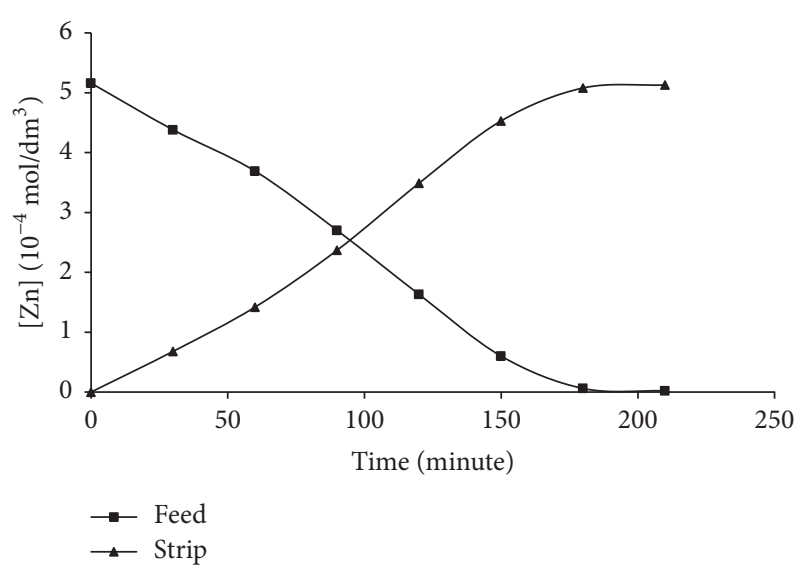

FIGURE 9: Variation in $\mathrm{Zn}$ (II) concentration in feed and strip solution against time (waste discharge liquor of galvanizing plant). Initial $\mathrm{Zn}$ (II) conc. in feed $=5.16 \times 10^{-4} \mathrm{~mol} / \mathrm{dm}^{3},[\mathrm{HCl}]$ in feed $=$ $2.0 \mathrm{~mol} / \mathrm{dm}^{3},[\mathrm{NaOH}]$ in stripping solution $=2.0 \mathrm{~mol} / \mathrm{dm}^{3}$, [TDDA] in membrane phase $=0.80 \mathrm{~mol} / \mathrm{dm}^{3}$.

\section{Recovery of Zinc (II) from Waste Discharge/Effluent of Galvanizing Plant}

The objective of this work was to design and develop SLM for recovery of $\mathrm{Zn}$ (II) from industrial waste effluents. The polypropylene as supported liquid membrane, TDDA as a carrier, was utilized for extraction of $\mathrm{Zn}$ (II) from waste discharge liquor of galvanizing plant. To check and assess the efficiency of SLM system, samples of galvanized industrial waste were collected from the different locations of the drain carrying the galvanizing industrial effluent. The effluent samples were analyzed using the aforementioned method as described in Experimental and the percent extraction and recovery of the $\mathrm{Zn}$ (II) metal ions were determined using atomic absorption spectrophotometry method. The data obtained is provided in Figure 9 which indicates approximately the complete extraction and recovery of $\mathrm{Zn}$ (II) after
210 minutes. This shows the suitability and effectiveness of this SLM for recovery of Zn (II).

\section{Recovery and Transport of $\mathrm{Zn}$ (II) from Galvanizing Plant Waste}

The present SLM was designed for the transport of $\mathrm{Zn}$ (II) metal ions and applied to zinc industrial effluents of galvanizing plants because zinc is one of the industrial important metals because of its applications and its use for protection, passivation, and decoration of some heavy elements. The data in Table 2 show that TDDA-polypropylene SLM system has significant transport efficiency for $\mathrm{Zn}$ (II) metal ions, that is, about $99.8 \%$, while other metal ions like $\mathrm{Co}, \mathrm{Cu}, \mathrm{Cd}, \mathrm{Mn}, \mathrm{Cr}$, and $\mathrm{Fe}$ show very little or more precisely negligible amount of transport that is 0.0 to $0.72 \%$ or in average $0.08 \%$ for Co, $0.23 \%$ for $\mathrm{Cu}, 0.15 \%$ for $\mathrm{Cd}, 0.36 \%$ for $\mathrm{Mn}, 0.06 \%$ for $\mathrm{Cr}$, and $0.28 \$$ for Fe. This much smaller amount of transport may be attributed to experimental error. If error factor is taken into account then TDDA-polypropylene SLM system is highly selective for transport of $\mathrm{Zn}$ (II) metal ions only. The data are represented in Tables 1 and 2.

\section{Conclusions}

The flux $\left(J_{\mathrm{Zn}(\mathrm{II})}\right)$ got increased by increasing carrier concentration up to $0.80 \mathrm{~mol} / \mathrm{dm}^{3}$, and, further increasing the carrier concentration, the transport of $\mathrm{Zn}$ (II) was found to decrease. The $\mathrm{Zn}$ (II) ions transport was increased by increasing $\mathrm{HCl}$ concentration in feed solution up to $2.0 \mathrm{~mol} / \mathrm{dm}^{3}$ and then decreased using a higher concentration of $\mathrm{HCl}$. The slope analysis studies of $\log J \eta$ of $\mathrm{Zn}$ (II) versus $\log [\mathrm{TDDA}]$ and $\log [\mathrm{HCl}]$ showed that 2.0 mole of each tri-n-dodecylamine and hydrogen are involved in the transport of $\mathrm{Zn}$ (II). The maximum transport of $\mathrm{Zn}$ (II) was achieved at $0.80 \mathrm{~mol} / \mathrm{dm}^{3}$ of TDDA in membrane phase and $2.0 \mathrm{~mol} / \mathrm{dm}^{3}$ of $\mathrm{HCl}$ and $\mathrm{NaOH}$ in feed and strip solution, respectively. It was also found to be coupled coion extraction pathway, as $\mathrm{H}^{+}, \mathrm{Cl}^{-}$, and $\mathrm{Zn}$ (II) travel in the same direction. Two moles of hydrogen 


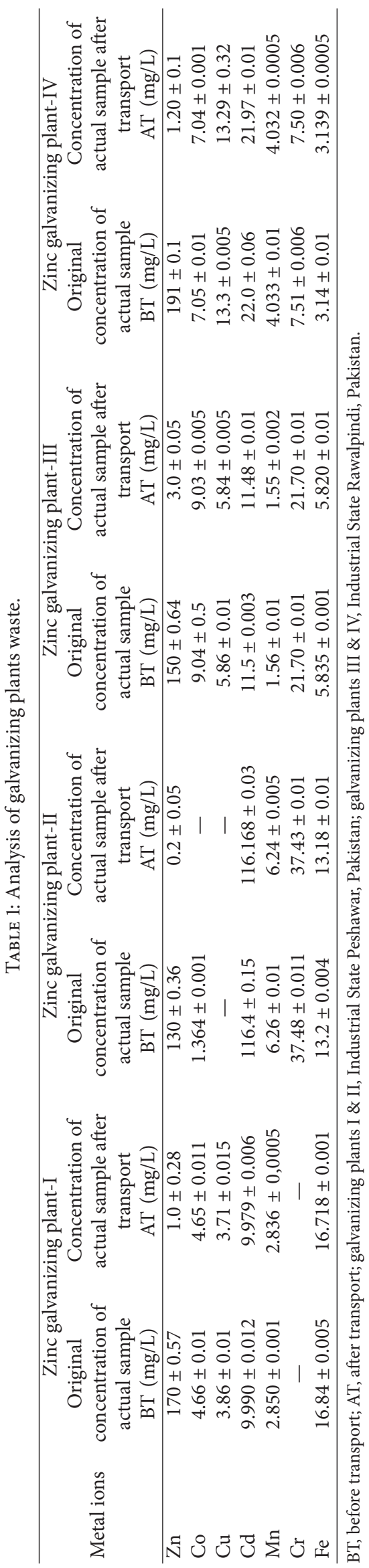


TABLE 2: Percent transport of metal ions from galvanizing plants waste.

\begin{tabular}{|c|c|c|c|c|}
\hline \multicolumn{5}{|c|}{ Percent transport of metal ions from waste of zinc galvanizing plants } \\
\hline Metal ions & $\begin{array}{c}\text { Zinc galvanizing } \\
\text { plant-I } \\
\text { (\% transport })\end{array}$ & $\begin{array}{c}\text { Zinc galvanizing } \\
\text { plant-II } \\
(\% \text { transport })\end{array}$ & $\begin{array}{c}\text { Zinc galvanizing } \\
\text { plant-III } \\
\text { (\% transport })\end{array}$ & $\begin{array}{c}\text { Zinc galvanizing } \\
\text { plant-IV } \\
(\% \text { transport })\end{array}$ \\
\hline $\mathrm{Zn}$ & 98.50 & 99.33 & 98 & 99.37 \\
\hline Co & 0.2 & 00 & 0.011 & 0.14 \\
\hline $\mathrm{Cu}$ & 0.38 & 00 & 0.5 & 0.07 \\
\hline $\mathrm{Cd}$ & 0.11 & 0.19 & 0.17 & 0.13 \\
\hline $\mathrm{Mn}$ & 0.49 & 0.31 & 0.64 & 0.02 \\
\hline $\mathrm{Cr}$ & 00 & 0.13 & 00 & 0.13 \\
\hline $\mathrm{Fe}$ & 0.72 & 0.15 & 0.25 & 0.03 \\
\hline
\end{tabular}

and TDDA interact with one mole of $\mathrm{Zn}$ (II) producing a complex $(\mathrm{LH})_{n} \cdot \mathrm{Zn}\left(\mathrm{Cl}_{2}+n\right)$, that is responsible for transport of $\mathrm{Zn}$ (II). This SLM system was effectively used for removal of $\mathrm{Zn}$ (II) to the waste discharge liquor of galvanizing plant of zinc.

\section{Conflicts of Interest}

The authors declare that there are no conflicts of interest regarding the publication of this paper.

\section{Acknowledgments}

The authors acknowledge Sarhad University of Science and Information Technology, Peshawar, KPK, Pakistan, for providing financial assistance to accomplish this work.

\section{References}

[1] R. A. Wuana and F. E. Okieimen, "Heavy metals in contaminated soils: a review of sources, chemistry, risks and best available strategies for remediation," ISRN Ecology, vol. 2011, Article ID 402647, 20 pages, 2011.

[2] D. W. Thomas, Metals and Their Compounds in the Environment, Edited by E. Merian, Wiley, Weinheim, Germany, 1991.

[3] ATSDR (Agency for Toxic Substances and Disease Registry), Toxicological Profile for Zinc, Public Health Service. U.S. Department of Health and Human Services, Atlanta, Ga, USA, 2005.

[4] A. S. Prasad, "Zinc deficiency," The British Medical Journal, vol. 326, no. 7386, pp. 409-410, 2003.

[5] K. M. Hambidge and N. F. Krebs, "Zinc deficiency: a special challenge," Journal of Nutrition, vol. 137, no. 4, pp. 1101-1105, 2007.

[6] G. J. Fosmire, "Zinc toxicity," American Journal of Clinical Nutrition, vol. 51, no. 2, pp. 225-227, 1990.

[7] L. Monser and N. Adhoum, "Modified activated carbon for the removal of copper, zinc, chromium and cyanide from wastewater," Separation and Purification Technology, vol. 26, no. 2-3, pp. 137-146, 2002.

[8] S. Liang, X. Guo, and Q. Tian, "Adsorption of $\mathrm{Pb}^{2+}$ and $\mathrm{Zn}^{2+}$ from aqueous solutions by sulfured orange peel," Desalination, vol. 275, no. 1-3, pp. 212-216, 2011.

[9] F. J. Alguacil and S. Martínez, "Solvent extraction of $\mathrm{Zn}$ (II) by cyanex 923 and its application to a solid-supported liquid membrane system," Journal of Chemical Technology and Biotechnology, vol. 76, no. 3, pp. 298-302, 2001.

[10] K. C. Sole, T. L. Ferguson, and J. B. Hiskey, "Solvent extraction of silver by cyanex 272, cyanex 302 and cyanex 301," Solvent Extraction and Ion Exchange, vol. 12, no. 5, pp. 1033-1050, 1994.

[11] P. M. Cole and K. C. Sole, "Zinc solvent extraction in the process industries," Mineral Processing and Extractive Metallurgy Review, vol. 24, no. 2, pp. 91-137, 2003.

[12] M. S. Lee and S.-H. Nam, "Solvent extraction of zinc from strong hydrochloric acid solution with Alamine336," Bulletin of the Korean Chemical Society, vol. 30, no. 7, pp. 1526-1530, 2009.

[13] F. M. Pang, S. P. Teng, T. T. Teng, and A. K. M. Omar, "Heavy metals removal by hydroxide precipitation and coagulationflocculation methods from aqueous solutions," Water Quality Research Journal of Canada, vol. 44, pp. 1-9, 2009.

[14] S. V. Plokhov, I. G. Matasova, V. A. Utkin, and V. Y. Vodzinskii, "Specific features of ion-exchange zinc(II) extraction from washing water of zinc plating," Russian Journal of Applied Chemistry, vol. 75, no. 6, pp. 950-953, 2002.

[15] K. H. Park, P. K. Parhi, and N.-H. Kang, "Studies on the removal of low content copper from the sea nodule leach liquor using the cationic resin TP 207," Separation Science and Technology, vol. 47, no. 10, pp. 1531-1541, 2012.

[16] J. D. Gyves and E. R. San Miguel, "Metal ion separations by supported liquid membranes," Industrial and Engineering Chemistry Research, vol. 38, no. 6, pp. 2182-2202, 1999.

[17] V. V. Prasad, D. J. Yogesh, D. S. Ajay et al., "Simultaneous extraction of neodymium and uranium using hollow fiber supported liquid membrane," Separation Science and Technology, vol. 49, no. 10, pp. 1509-1520, 2014.

[18] B. Mokhtari and K. Pourabdollah, "Inclusion separation of alkali metals in emulsion liquid membranes by nanobaskets of calix[4]crown-3," Brazilian Journal of Chemical Engineering, vol. 29, no. 4, pp. 783-793, 2012.

[19] S. B. Kanungo and R. Mohapatra, "Coupled transport of Zn (II) through a supported liquid membrane containing bis $(2,4,4-$ trimethyl pentyl) phosphinic acid in kerosene. 1. A model for the rate process involving binary and ternary complex species," Journal of Membrane Science, vol. 105, pp. 217-226, 1995.

[20] O. N. Ata, A. V. Beşe, S. Çolak, B. Dönmez, and A. Çakıcı, "Effect of parameters on the transport of zinc ion through supported liquid membrane," Chemical Engineering and Processing: Process Intensification, vol. 43, no. 7, pp. 895-903, 2004.

[21] R. Wódzki and P. Szczepański, "Simultaneous recovery and separation of $\mathrm{Zn}^{2+}$ and $\mathrm{Cu}^{2+}$ in hybrid membrane systems," 
Separation and Purification Technology, vol. 41, no. 3, pp. 289297, 2005.

[22] M. Ulewicz, W. Walkowiak, J. Gega, and B. Pospiech, "Zinc (II) selective removal from other transition metal by solvent extraction and transport through polymer inclusion membranes with D2EHPA," Ars Separatoria Acta, vol. 2, pp. 47-55, 2003.

[23] J. Kozlowska, C. A. Kozłowski, and J. J. Koziol, “Transport of $\mathrm{Zn}(\mathrm{II}), \mathrm{Cd}(\mathrm{II})$, and $\mathrm{Pb}(\mathrm{II})$ across CTA plasticized membranes containing organophosphorous acids as an ion carriers," Separation and Purification Technology, vol. 57, no. 3, pp. 430-434, 2007.

[24] M. Torz, K. Alejski, and J. Szymanowski, "Modelling of zinc (II) extraction from model hydrochloric acid solutions in hollow fiber modules," Physicochemical Problems of Mineral Processing, vol. 37, pp. 97-105, 2003.

[25] J.-C. Lee, J. Jeong, B.-S. Kim, M. S. Kim, and M. Kobayashi, "Separation of copper and zinc ions by hollow fiber supported liquid membrane containing LIX84 and PC-88A," Materials Transactions, vol. 45, no. 6, pp. 1915-1919, 2004.

[26] S. U. Rehman, G. Akhtar, M. A. Chaudry, N. Bukhari, Najeebullah, and N. Ali, "Mn (VII) ions transport by triethanolamine cyclohexanone based supported liquid membrane and recovery of Mn (II) ions from discharged zinc carbon dry battery cell," Journal of Membrane Science, vol. 366, no. 1-2, pp. 125-131, 2011.

[27] S. U. Rehman, G. Akhtar, and M. A. Chaudry, "Coupled transport of $\mathrm{Tl}^{3+}$ through triethanolamine-xylene-polypropylene supported liquid membranes," Journal of Industrial and Engineering Chemistry, vol. 18, no. 1, pp. 492-498, 2012.

[28] S. U. Rehman, G. Akhtar, M. A. Chaudry, K. Ali, and N. Ullah, "Transport of $\mathrm{Ag}^{+}$through tri-n-dodecylamine supported liquid membranes," Journal of Membrane Science, vol. 389, pp. 287293, 2012.

[29] S. Ur Rehman, G. Akhtar, and M. A. Chaudry, "Coupled transport of $\mathrm{Pb}^{2+}$ through tri-n-octylamine-xylene-polypropylene supported liquid membranes," Canadian Journal of Chemical Engineering, vol. 91, no. 6, pp. 1140-1152, 2013.

[30] S. A. Ansari, P. K. Mohapatra, and V. K. Manchanda, "Recovery of actinides and lanthanides from high-level waste using hollow-fiber supported liquid membrane with TODGA as the carrier," Industrial and Engineering Chemistry Research, vol. 48, no. 18, pp. 8605-8612, 2009.

[31] F. Holleman, A. E. Wiberg, and N. Wiberg, Zink, Lehrbuch der Anorganischen Chemie, Walter de Gruyter, Berlin, Germany, 91th-100th edition, 1985. 

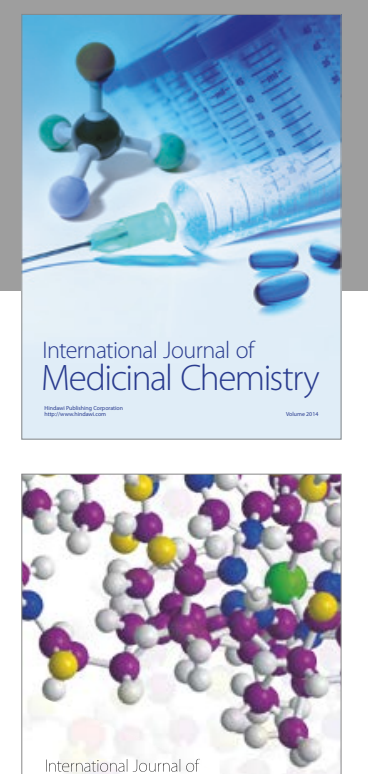

Carbohydrate Chemistry

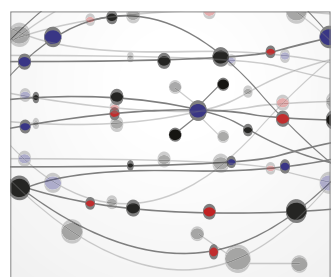

The Scientific World Journal
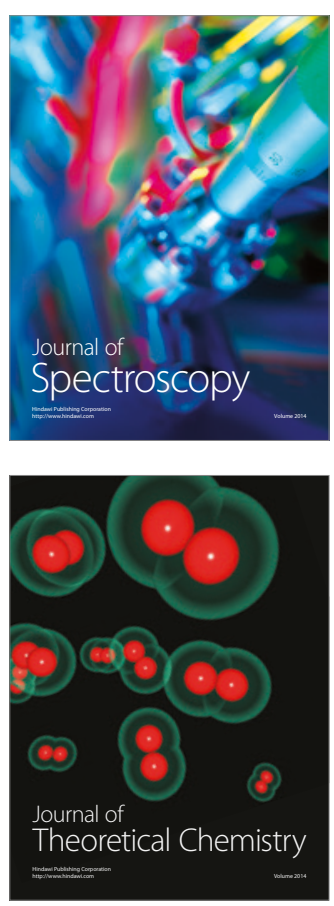
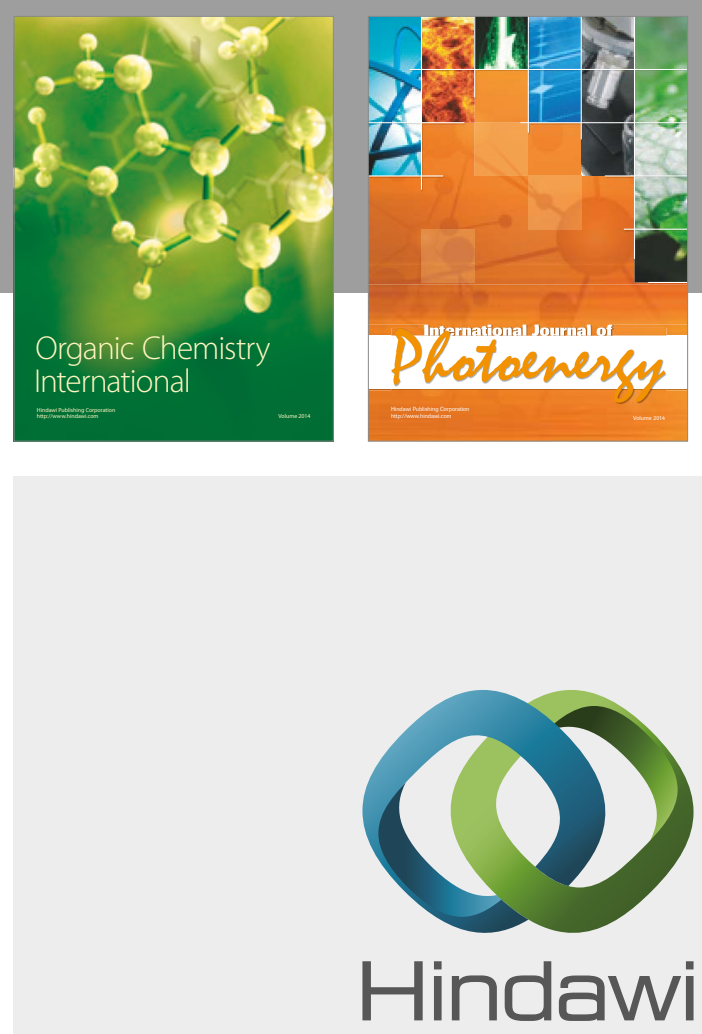

Submit your manuscripts at

https://www.hindawi.com

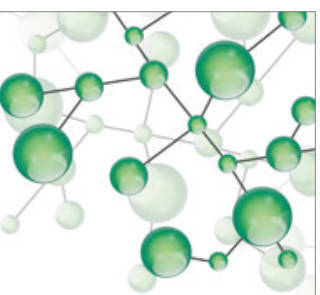

International Journal of

Inorganic Chemistry

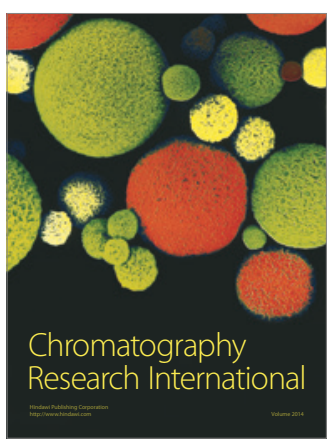

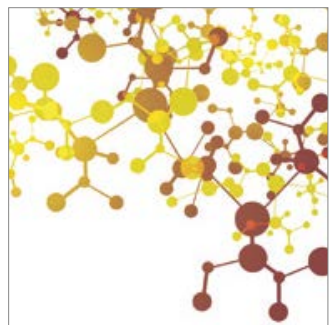

Applied Chemistry
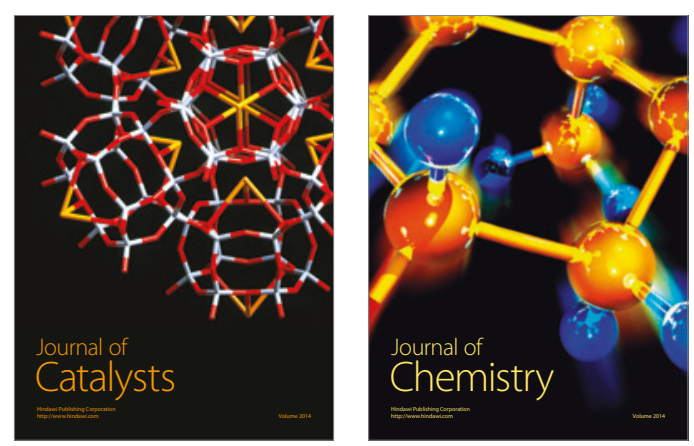
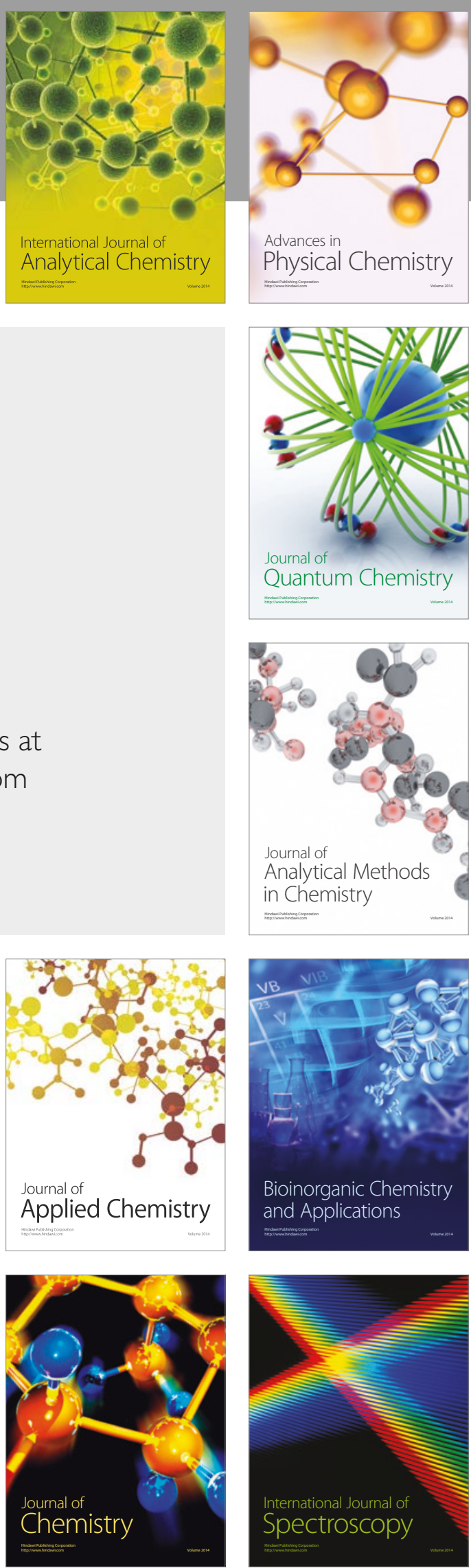